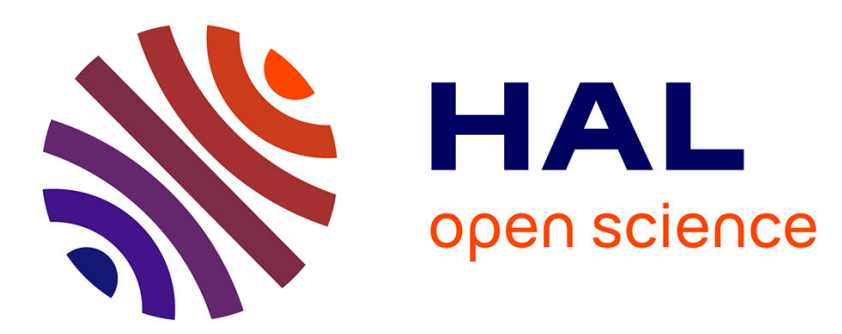

\title{
A continental-scale analysis of fish assemblage functional structure in European rivers
}

\author{
Maxime Logez, Pierre Bady, Andreas Melcher, Didier Pont
}

\section{To cite this version:}

Maxime Logez, Pierre Bady, Andreas Melcher, Didier Pont. A continental-scale analysis of fish assemblage functional structure in European rivers. Ecography, 2013, 36 (1), pp.80-91. 10.1111/j.16000587.2012.07447.x . hal-00835204

\section{HAL Id: hal-00835204 https://hal.science/hal-00835204}

Submitted on 18 Jun 2013

HAL is a multi-disciplinary open access archive for the deposit and dissemination of scientific research documents, whether they are published or not. The documents may come from teaching and research institutions in France or abroad, or from public or private research centers.
L'archive ouverte pluridisciplinaire $\mathbf{H A L}$, est destinée au dépôt et à la diffusion de documents scientifiques de niveau recherche, publiés ou non, émanant des établissements d'enseignement et de recherche français ou étrangers, des laboratoires publics ou privés. 


\title{
A continental-scale analysis of fish assemblage functional structure in European rivers
}

\author{
Maxime Logez ${ }^{*}$, Pierre Bady ${ }^{\dagger \dagger}$, Andreas Melcher ${ }^{\diamond}$ and Didier Pont ${ }^{*}$. \\ * Irstea, UR HBAN, 1 rue Pierre-Gilles de Gennes - CS 10030, F-92761 Antony, France. \\ $\dagger$ University Hospital (CHUV), Rue du Bugnon, 46, 1011 Lausanne, Switzerland. \\ \$ Swiss Institute of Bioinformatics, Bioinformatics Core Facility, Quartier UNIL-Sorge Bâtiment \\ Génopode, 1015 Lausanne, Switzerland \\ $\checkmark$ Department of Water, Atmosphere and Environment, Institute of Hydrobiology and Aquatic Ecosystem \\ Management, University of Natural Resources and Applied Life Sciences, Max-Emanuel-Strasse 17, 1180 \\ Vienna, Austria. \\ Correspondence: Maxime Logez \\ Address: Irstea, UR HBAN, 1 rue Pierre-Gilles de Gennes - CS 10030, F-92761 Antony, France. \\ Email: maxime.logez@irstea.fr

\section{Reference of the paper:} \\ Logez, M., P. Bady, A. Melcher \& D. Pont. 2013. A continental-scale analysis of fish assemblage \\ functional structure in European rivers. Ecography 36:80-91. \\ The definitive version is available at: \\ http://onlinelibrary.wiley.com/doi/10.1111/j.1600-0587.2012.07447.x/full
}

\section{Summary}

The theory of traits (life-history, ecological and biological traits) states that a species' characteristics might enable its persistence and development in given environmental conditions. If environment is the major factor controlling functional assemblage structure, species with similar attributes are expected to inhabit a similar environment. This study uses trait states in 849 European riverine fish assemblages to analyze the influence of environment, phylogeny and biogeography on the functional structure of these assemblages. European fish assemblages were highly structured and two main syndromes (a suite of coevolved traits) were observed: (1) assemblages dominated by stenothermal intolerant individuals and (2) assemblages dominated by eurythermal, eurytopic and tolerant individuals. Temperature and stream physical structure were the two main environmental factors explaining the diversity of fish assemblage functional structures, while the influence of biogeographic factors was weak, once environment was taken into account. This suggests that, whatever the regional species pool, similar assemblage functional structures will be found in similar environmental conditions. The phylogenetic relatedness between species might also explain to some extent the associations between the species traits observed among European fish assemblages. 


\section{Introduction}

The theory of life history states that natural selection designed co-adapted traits to solve particular ecological problems (Stearns 1992). The set of traits (morphological, behavioural and demographic) might allow species to develop and persist in a given environment.

Concerning freshwater fishes, two main theories relate habitat and species traits. The 'habitat templet' theory (Southwood 1977, 1988) states that the spatio-temporal variability of habitat drives the selection of species traits. If the local environment were the major selective force upon species traits, a similar local environment would select species with a similar set of strategies. The 'landscape filters' theory (Tonn et al. 1990, Poff 1997) states that local assemblages are the result of different hierarchical filters acting at various spatial scales (e.g. from watershed to microhabitat in streams). The presence and abundance of a species in an assemblage depend on its suite of traits, given that only adapted traits enable species to pass through environmental filter sieves (Tonn et al. 1990, Keddy 1992, Poff 1997). If environment were the major factor controlling functional assemblage structure, traits are expected to be under-dispersed because species living in a similar environment would present similar attributes (Keddy 1992, Weiher and Keddy 1995, Diaz et al. 1998, Weiher and Keddy 1999, Cornwell et al. 2006). Consequently, assemblages living under similar environmental conditions would display convergent functional structure (Orians and Paine 1983). This hypothesis has led to an increasing number of comparisons between geographically and phylogenetically distant assemblages (Wiens 1991, Kelt et al. 1996). In contrast, if species interaction (e.g. competition) were the major factor controlling functional assemblage structure, over-dispersion is assumed to occur (Weiher and Keddy 1995), because species similarity would limit the amount of resources available to each species (MacArthur and Levins 1967). Several studies have supported the action of each mechanism on functional assemblage structure and even of both mechanisms conjointly (Cornwell and Ackerly 2009).

For fish, the theory of life-history strategies is well developed and tested. The 'opportunisticequilibrium-periodic' model proposed by Winemiller and Rose (1992) is based on the habitat template theory, using multiple demographic traits (Winemiller 2005). This life-history model distinguishes between species by the optimization of their generation time, their age-specific survivorship and their age-specific fecundity (Winemiller 2005) in relation to environmental gradients. The three strategies explicitly incorporate trade-offs between traits and have been shown to apply across major biogeographic regions (Vila-Gispert et al. 2002) and to be related to environmental conditions (e.g. Blanck and Lamouroux 2007, Tedesco et al. 2008). However, differences in the species pool between regions (Banarescu 1989, Reyjol et al. 2007, Schleuter et al. 2012) and phylogenetic constraints (Vitt and Pianka 2005) may make it more difficult to identify clear-cut strategies (suites of coevolved traits related to a single major activity) or syndromes (suites of coevolved traits related to multiple major activities) (Poff et al. 2006, 
Frimpong and Angermeier 2010). For example, local assemblages living in similar environmental conditions but located in different regions might have a distinct functional structure because of species being selected from different regional species pools, or some traits might co-occur in assemblages not because of environmental drivers but because they were inherited from a common ancestor (Smith and Ganzhorn 1996, Webb et al. 2002, Vitt and Pianka 2005).

Trait-based approaches present several advantages compared to taxonomic ones. First, establishing classifications of species based on their attributes rather than their taxonomy is assumed to relate species directly or indirectly to ecosystem functioning (Lavorel and Garnier 2002). Second, aggregating species based on their morphological (Melville et al. 2006), ecological or biological (Usseglio-Polatera et al. 2000, Hoeinghaus et al. 2007) characteristics makes it possible to compare systems and assemblages composed of different species pools (Kelt et al. 1996, Lamouroux et al. 2002, Ibañez et al. 2009), whereas patterns derived from taxonomic composition may first reflect the role played by geographical and historical factors in current species distribution (Hoeinghaus et al. 2007).

Aquatic habitats offer many environmental gradients along which species might develop adaptive strategies, and traits have been defined for almost all aquatic biocenosis components (e.g. Winemiller and Rose 1992, Usseglio-Polatera et al. 2000, Willby et al. 2000, Barnett et al. 2007). Several studies have compared the composition of freshwater fish assemblages with regard to their ecological and/or biological traits, aiming to find general patterns such as assemblage convergence (Lamouroux et al. 2002, Irz et al. 2007, Ibañez et al. 2009, Logez et al. 2010), trait-environment associations (Goldstein and Meador 2004, Ibañez et al. 2007, Tedesco et al. 2008) or trait dispersion within assemblages (Mason et al. 2007). Nevertheless, trait states were most often considered separately as distinct entities and the different hypotheses were tested trait by trait (but see Blanck et al. 2007, Mims et al. 2010, Olden and Kennard 2010).

The association between biological and ecological trait states within assemblages has received limited attention at a continental scale (e.g. Statzner et al. 2004), especially for riverine fish. Working at such a large spatial extent makes it possible to encompass both a high diversity of fish assemblages (e.g. Hoeinghaus et al. 2007, Melcher et al. 2007) and a large variety of environmental conditions (Koster 2005). Environmental factors are expected to be more independent at a large spatial extent than at national or watershed scales, making it easier to disentangle their independent effects on fish assemblage functional structure. For instance, while temperature and stream physical structure have been acknowledged to be two major factors controlling fish assemblages (e.g. Petts and Amoros 1996, Matthews 1998, Allan and Castillo 2007), at a small spatial extent these two factors very often evolve conjointly, which makes it difficult to assess their relative importance. 
The aim of the present paper was to analyze and quantify: (1) the association between trait states in European riverine fish assemblages and the phylogenetic constraints, (2) the influence of the environment on fish assemblage functional structure, (3) the relative influence of stream physical structure and temperature on fish assemblage functional structure and (4) the influence of the regional species pool before and after taking into account the influence of environmental conditions. For this purpose, five data sets were used: a set of ecological and biological traits for 88 European fish species, species phylogenetic relatedness, the fauna at the sampling sites and the sites' environmental conditions.

\section{Methods}

Sampling site selection

The data used came from fish surveys of 13 European countries conducted by several laboratories and government environmental agencies (1981-2007, 95\% of the data collected after 1990). The sites were sampled by electrofishing during a low-flow period. They were sampled either by wading ( $85 \%$ of sites) or by boat, depending on the river depth. All sites were located in permanent streams. To homogenize the sampling between regions, only fish collected during the first pass were considered (Logez and Pont 2011). Eighty-eight species were sampled, and only sites for which at least two species were caught were considered, in order to avoid monospecific assemblages.

All sites were selected to be pristine or only slightly influenced by human pressures at the reach scale, in order to reduce the bias due to modifications of fish assemblage structure in relation to human activities (Pont et al. 2006). The sites chosen had: good water quality, no or few modifications of the river cross-section, river channel and water flow, no impoundment, no or few alterations of the river banks and bottom habitat, and no major alteration of connectivity. This selection limited the representation of large rivers in the data set used. All the data were extracted from the database compiled during the European EFI+ project. This project aimed to develop bioassessment methods in accordance with the Water Framework Directive (European Union 2000). For greater detail see http://efi-plus.boku.ac.at/index.htm.

The network structure of streams and the ability of fish to move within this network might limit independence between the sites selected. To reduce potential bias due to spatial autocorrelation in the data set used, the minimum distance between sites belonging to the same catchment was set at $10 \mathrm{~km}$. This distance was chosen to limit the spatial autocorrelation that might result from fish migration between sites. Once these sites were selected, some geographical areas remained over-represented in the data set. To reduce their influence in the analyses, a maximum of 30 sites per spatial unit (two degrees of latitude and longitude) was set and sites were randomly selected. Finally, the data set used consisted of 849 sampling sites (selected from 14221 available sites) distributed throughout Europe (Fig. 1). 


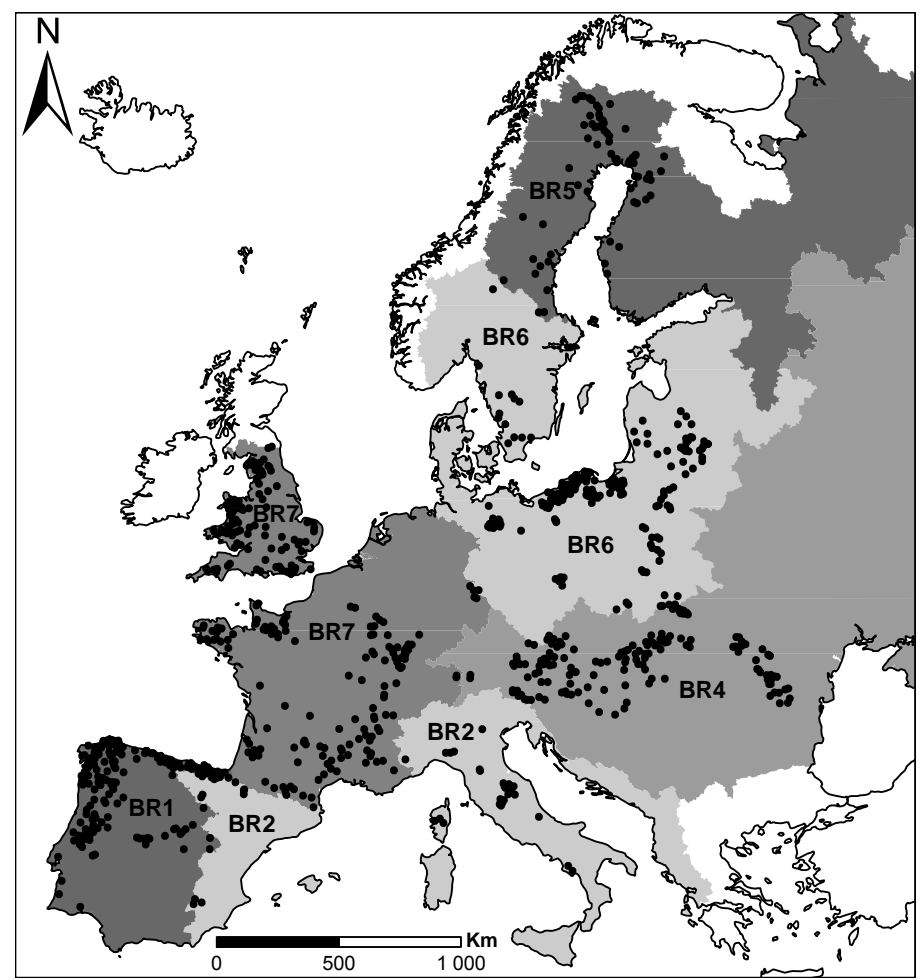

Fig. 1. Location of the 849 sampling sites among the biogeographic regions adapted from Reyjol et al (2007).

\section{Environmental variables}

The local environment (site scale) was characterized by six environmental variables. River slope (SLOP; 0-194.5 m.km ${ }^{-1}$, log-transformed), July mean air temperature (TJULY; 11.9-25.1 ${ }^{\circ} \mathrm{C}$ ) and air thermal amplitude between July and January (TDIF; 8.6-29 $\mathrm{C}$ ) are fundamental descriptors of river habitat at the reach scale (Pont et al. 2005). Temperatures were estimated using a GIS and data from WordClim (Hijmans et al. 2005). In addition, bottom sediment structure (SED) was considered, but in a simplified manner, to obtain comparable information for such a large data set: small (sand, silt), medium (cobble, pebble), and large (rock, block). SED was estimated visually on the field at the reach scale.

Hydro-geomorphological functioning also includes key processes structuring river habitats and their associated fish assemblages. These processes can be described by using synthetic variables such as the river size (distance from source and upstream drainage area), the hydrological regime (pluvial dominated vs. glacial-nival), the geomorphological types (meandering, braided, constraint; Petts and Amoros 1996), and the presence of a floodplain (Junk et al. 1989, Poff and Allan 1995). To reduce the number of variables and the multicollinearity between them, these quantitative and qualitative variables were summarized in two synthetic independent variables, using Principal Component Analysis (Hill and Smith 1976): the first PCA axis (SYNGEO1) mainly describes the river size gradient and the common occurrence of a floodplain in the 
downstream part. The second PCA axis (SYNGEO2) describes the contrast between meandering rivers with a pluvial regime and other river types (Logez and Pont 2011). These two variables accounted for $53 \%$ of the hydro-geomorphological variability.

\section{Biogeographic units}

The potential effect of biogeographic differences between European regions (Schleuter et al. 2012) was assessed using the biogeographic regions defined by Reyjol et al. (2007). These authors clustered river basins in larger units (biogeographic regions), based on species pool similarities.

\section{Ecological and biological traits}

A previous classification of biological and ecological traits of European fish species (Noble et al. 2007) was revised and completed during the European EFI+ project (http://efi-plus.boku.ac.at/). From these biological and ecological traits, 11 were chosen with regard to: species reproduction, trophic position in the food webs, affinity to several habitat characteristics, sensitivity to water quality and habitat alteration, and migratory behavior (Table 1). For each trait, each species was assigned to one of the different states. All 88 species represented in the sampling site data set were described, providing an accurate description of the trait composition of the fish assemblages (11 traits, 40 states). 
Table 1. Description of the states of the eleven biological and ecological traits considered.

\begin{tabular}{|c|c|}
\hline Trait & States \\
\hline \multirow{2}{*}{ Temperature tolerance } & Eurythermal (EUTHER): species able to withstand a large range of temperature \\
\hline & Stenothermal (STTHER): species able to withstand a narrow range of temperature \\
\hline \multirow{3}{*}{ Tolerance to oxygen } & Intolerant (O2INTOL): species requiring more than 6 mg. $\mathrm{L}^{-1}$ \\
\hline & Intermediate $(\mathrm{O} 2 \mathrm{IM})$ : species relatively tolerant to low oxygen concentration \\
\hline & Tolerant (O2TOL): species able to live in water with less than $3 \mathrm{mg} \cdot \mathrm{L}^{-1}$. \\
\hline \multirow{3}{*}{$\begin{array}{l}\text { Tolerance to habitat } \\
\text { degradation }\end{array}$} & Intolerant (HINTOL) \\
\hline & Intermediate (HIM) \\
\hline & Tolerant (HTOL) \\
\hline \multirow{7}{*}{ Adult trophic guild } & Detritivorous (DETR): adult diet composed of a high proportion of detritus \\
\hline & Herbivorous (HERB): adult diet composed of at least $75 \%$ plant material \\
\hline & Insectivorous (INSV): adult diet composed of at least $75 \%$ insect individuals \\
\hline & Omnivorous (OMNI): adult diet composed of more than $25 \%$ plant material and more than $25 \%$ animal material \\
\hline & Parasitic (PARA): adult exhibiting a parasitic feeding mode \\
\hline & Piscivorous (PISC): adult diet composed of more than $75 \%$ fish \\
\hline & Planktivorous (PLAN): adult diet composed of more than $75 \%$ phytoplankton or zooplankton \\
\hline \multirow{2}{*}{ Feeding habitat } & Benthic (B): species preferring to live near the bottom, from where they feed \\
\hline & Water column (WC): species that live and feed in the water column \\
\hline \multirow{3}{*}{$\begin{array}{l}\text { Affinity to flow velocity } \\
\text { (habitat) }\end{array}$} & Limnophilic (LIMNO): species preferring to live in slow-flowing to stagnant conditions \\
\hline & Rheophilic (RH): species preferring to live in high-flow conditions \\
\hline & Eurytopic (EURY): species with a wide tolerance to flow conditions \\
\hline \multirow{3}{*}{ Spawning habitat } & (LIPAR) species preferring to spawn in stagnant water \\
\hline & (RHPAR) species preferring to spawn in running waters \\
\hline & (EUPAR) species without clear spawning preferences \\
\hline \multirow{9}{*}{ Reproduction } & $\begin{array}{l}\text { Ariadnophilic (ARIAD): species are specialized in nested building, behaviour very often associated with parental } \\
\text { care }\end{array}$ \\
\hline & Lithopelagophilic (LIPE): species spawning on rocks and gravels with pelagic free embryos \\
\hline & $\begin{array}{l}\text { Lithophilic (LITH): species spawning exclusively on gravel, rocks, stones, rubbles or pebbles and with } \\
\text { photophobic hatchlings }\end{array}$ \\
\hline & Ostracophilic (OSTRA): species spawning in bivalve molluscs \\
\hline & Pelagophilic (PELA): species spawning in pelagic zone \\
\hline & $\begin{array}{l}\text { Phyto-lithophilic (PHLI): species depositing their eggs in clear water habitats on submerged plants or on other } \\
\text { submerged items such as logs, gravel and rocks with photophobic larvae }\end{array}$ \\
\hline & Phytophilic (PHYT): species depositing their eggs in clear water habitats on submerged plants \\
\hline & Psammophilic (PSAM): species spawning on roots or grass above sandy bottom or on the sand itself \\
\hline & Speleophilic (SPEL): species spawning in interstitial spaces, crevices or caves \\
\hline \multirow{3}{*}{ Reproductive behaviour } & Single (SIN): species with a single spawning event during the reproductive season \\
\hline & $\begin{array}{l}\text { Fractional (FR): species which either spawn repeatedly in a season or with different components of their } \\
\text { populations spawning at different times }\end{array}$ \\
\hline & Protracted (PRO): species spawning over a long period during the reproductive season \\
\hline \multirow{2}{*}{ Parental care } & (PROT) species presenting egg or larvae life stages with protection \\
\hline & (NOP) species with no protection for early life stages \\
\hline \multirow{4}{*}{ Migration behaviour } & Resident (RESID): species moving over small areas within particular river segment \\
\hline & Potamodromous (POTAD): species migrating within the inland waters of a river \\
\hline & $\begin{array}{l}\text { Anadromous (LMA): species living as older juveniles and sub-adults in the sea, and migrating up rivers to spawn } \\
\text { at maturity }\end{array}$ \\
\hline & $\begin{array}{l}\text { Catadromous (LMC): species with early life stage living in fresh water and migrating down rivers to spawn in } \\
\text { the sea at maturity }\end{array}$ \\
\hline
\end{tabular}

\section{Species phylogenetic relatedness}

A phylogeny of European fish species was built based on cytochrome b (a mitochondrial DNA gene, 1141 base pairs). The sequences were obtained from GenBank and aligned with 
Clustal X 2 (version 2.1, Larkin et al. 2007). The phylogeny was estimated with the Bayesian model GTR $+\mathrm{I}+\mathrm{G}$ (Tavaré 1986), using MrBayes software (version 3.2; Ronquist and Huelsenbeck 2003). The phylogeny was computed for 81 species out of the 88 sampled, due to missing sequences. The patterns derived from this phylogeny should be representative of the phylogenetic influence because the seven missing species were poorly represented in the 849 fish assemblages (sampled in less than $3.3 \%$ of the sites; total catches $<0.5 \%$ ).

\section{Statistical analysis}

Five initial data sets were available: species abundance per site ( 849 sites $\times 88$ species), trait description per species (88 species $\times 40$ states), phylogenetic distances between species, environmental description ( 849 sites $\times 6$ descriptors) and site assignment by biogeographic region. These data were used independently or in combination for the statistical analyses.

The phylogenetic pattern of trait associations was studied, first analyzing the associations of species trait states with a multiple correspondence analysis (MCA). For each trait, rare states were grouped into a common trait state (called rare) to limit their influence in the MCA. The MCA table was then analyzed using a phylogenetic principal component analysis (pPCA; Jombart et al. 2010a,b). pPCA is designed to 'summarize a set of traits into a few synthetic variables exhibiting global or local phylogenetic structures' (Jombart et al. 2010a, b) by constraining the principal components (Dray et al. 2008). The phylogenetic signal in each individual trait was tested using the root skewness test developed by Pavoine et al. (2010). For each trait we first computed the distance between each pair of species (Pavoine et al. 2009) and then tested the distribution of diversity between traits along the phylogenetic tree, using the root skewness test (Pavoine et al. 2010). To compute the $p$-values associated with these tests, 999 random permutations were performed.

As the main objective was to compare the composition of fish assemblages between sites with regard to traits, the first two data sets were combined to obtain the relative frequency of each trait state for a given assemblage: $T_{i j}=\sum_{\text {species }} A_{p} \times a_{i j}$,where $T_{i j}$ is the proportion of the $j^{\text {th }}$ state of the $i^{\text {th }}$ trait in a given sampling site, $A_{p}$ is the relative abundance of the species $p$, and $a_{i j}$ the affinity of the species to the trait state considered ( 1 if the species displayed this state or else 0 ).

The relation between trait states in fish assemblages was analyzed with a PCA based on a variance-covariance matrix. The same weight was assigned to each trait, i.e. the sum of the different states for a given trait in a given assemblage equals one.

To investigate the influence of the environment on fish assemblage functional structure, a redundancy analysis (RDA) was used (Rao 1964, Lebreton et al. 1991, Legendre and Legendre 
1998). F-tests based on 999 permutations were used to test the significance of the axes of the RDA, the global effect of the environment (all variables taken into account) and the effect of each environmental variable (Legendre et al. 2011, Oksanen et al. 2011). The relative effects of temperature (TJULY and TDIF) and the physical characteristics of streams (SLOP, SED, SYNGEO1 and SYNGEO2) on fish assemblage functional structure were quantified using the variation partitioning method (Legendre and Legendre 1998), based on the adjusted canonical coefficient of determination (Peres-Neto et al. 2006). The multicollinearity between environmental factors was assessed by computing the General Variance Inflation Factor (GVIF) (Fox 2002).

The significance of the biogeographic effect on fish assemblage functional structure was tested before and after controlling for the environmental effect, using RDA and partial RDA, respectively (Lebreton et al. 1991, Legendre and Legendre 1998), and F-tests based on 999 permutations (Legendre et al. 2011, Oksanen et al. 2011).

All statistical analyses were performed using the statistical software R v2.14.1 (R Development Core Team 2011) and, in particular, the ade4 (v1.4-17; Chessel et al. 2004), vegan (v1.17-11; Oksanen et al. 2011) and adephylo (v1.1-2; Jombart et al. 2010b) libraries.

\section{Results}

Functional traits

In the samples, 88 species distributed among 15 families were recorded. The most highly represented family in the guild matrix was the Cyprinidae with 49 species, whereas the Acipenseridae, Anguillidae, Esocidae, Lotidae, Nemacheilidae, Pleuronectidae and Siluridae were represented by only one species each, and the Cobitidae, Cottidae, Gasterosteidae, Gobiidae, Percidae, Petromyzontidae and Salmonidae by between two and eight species each.

The Cyprinidae family exhibited the widest range of trait states, with at least one species of this family represented in almost all trait states (Table 2). The Salmonidae and Cottidae exhibited very close strategies; they are all stenothermal, oxygen- and habitat-intolerant, and rheophilic, with a single spawning event during the reproductive season (Table 2). 
Table 2. Distribution of trait states among families.

\begin{tabular}{|c|c|c|c|c|c|c|c|}
\hline & Cobitidae & Cottidae & Cyprinidae & Gobiidae & Percidae & Salmonidae & Others \\
\hline STTHER & 0 & 2 & 2 & 0 & 0 & 4 & 3 \\
\hline EUTHER & 5 & 0 & 47 & 6 & 8 & 0 & 11 \\
\hline O2INTOL & 0 & 2 & 10 & 0 & 2 & 4 & 3 \\
\hline O2IM & 4 & 0 & 26 & 6 & 6 & 0 & 10 \\
\hline O2TOL & 1 & 0 & 13 & 0 & 0 & 0 & 1 \\
\hline HINTOL & 2 & 2 & 18 & 0 & 2 & 4 & 3 \\
\hline HIM & 2 & 0 & 18 & 2 & 4 & 0 & 7 \\
\hline HTOL & 1 & 0 & 13 & 4 & 2 & 0 & 4 \\
\hline$\overline{\text { DETR }}$ & 0 & 0 & 3 & 0 & 0 & 0 & 2 \\
\hline HERB & 0 & 0 & 2 & 0 & 0 & 0 & 0 \\
\hline INSV & 5 & 2 & 20 & 6 & 5 & 2 & 4 \\
\hline OMNI & 0 & 0 & 21 & 0 & 0 & 0 & 3 \\
\hline PARA & 0 & 0 & 0 & 0 & 0 & 0 & 2 \\
\hline PISC & 0 & 0 & 1 & 0 & 3 & 2 & 3 \\
\hline PLAN & 0 & 0 & 2 & 0 & 0 & 0 & 0 \\
\hline $\mathrm{B}$ & 5 & 2 & 27 & 6 & 6 & 0 & 9 \\
\hline WC & 0 & 0 & 22 & 0 & 2 & 4 & 5 \\
\hline LIMNO & 1 & 0 & 8 & 0 & 0 & 0 & 1 \\
\hline RH & 4 & 2 & 25 & 0 & 4 & 4 & 6 \\
\hline EURY & 0 & 0 & 16 & 6 & 4 & 0 & 7 \\
\hline LIPAR & 1 & 0 & 7 & 0 & 0 & 0 & 4 \\
\hline RHPAR & 1 & 2 & 31 & 2 & 3 & 4 & 5 \\
\hline EUPAR & 3 & 0 & 11 & 4 & 5 & 0 & 5 \\
\hline ARIAD & 0 & 0 & 0 & 0 & 0 & 0 & 2 \\
\hline LIPE & 0 & 0 & 0 & 0 & 0 & 0 & 0 \\
\hline LITH & 0 & 0 & 28 & 2 & 3 & 4 & 7 \\
\hline OSTRA & 0 & 0 & 1 & 0 & 0 & 0 & 0 \\
\hline PELA & 0 & 0 & 0 & 0 & 0 & 0 & 2 \\
\hline PHLI & 0 & 0 & 8 & 1 & 5 & 0 & 0 \\
\hline PHYT & 5 & 0 & 9 & 0 & 0 & 0 & 3 \\
\hline PSAM & 0 & 0 & 3 & 0 & 0 & 0 & 0 \\
\hline SPEL & 0 & 2 & 0 & 3 & 0 & 0 & 0 \\
\hline SIN & 1 & 2 & 28 & 2 & 5 & 4 & 10 \\
\hline FR & 4 & 0 & 19 & 0 & 1 & 0 & 3 \\
\hline PRO & 0 & 0 & 2 & 4 & 2 & 0 & 1 \\
\hline PROT & 0 & 2 & 2 & 6 & 2 & 2 & 4 \\
\hline NOP & 5 & 0 & 47 & 0 & 6 & 2 & 10 \\
\hline RESID & 5 & 2 & 27 & 6 & 7 & 0 & 7 \\
\hline POTAD & 0 & 0 & 22 & 0 & 1 & 3 & 3 \\
\hline LMA & 0 & 0 & 0 & 0 & 0 & 1 & 2 \\
\hline LMC & 0 & 0 & 0 & 0 & 0 & 0 & 2 \\
\hline
\end{tabular}

Phylogenetic influence on species ecological traits

The first global principal component of the pPCA contrasted lampreys and chondrostoms to Blicca bjoerkna, Rhodeus amarus, gobiids, percids (except the genus Zingel), cottids and gasterosteids (Fig. 2). This distinction was mainly based on the trophic guilds (rare feeding guild, DETR) and the reproduction strategies (PROT, PRO, and rare reproductive behaviors) (Table 3).

The second global principal component differentiated species principally on their thermal tolerance (STTHER), and, to a lesser extent, on their intolerance of low concentrations of oxygen 
(O2INTOL) and on their piscivorous (PISC) feeding regime (Table 3). It contrasted bream, Scardinius erythrophthalmus, Iberian chondrostoms, Achondrostoma oligolepis, tench, carp, Misgurnus fossilis and other loaches to European brook lamprey, minnow, spirlin, burbot, salmonids, grayling and cottids (Fig. 2).
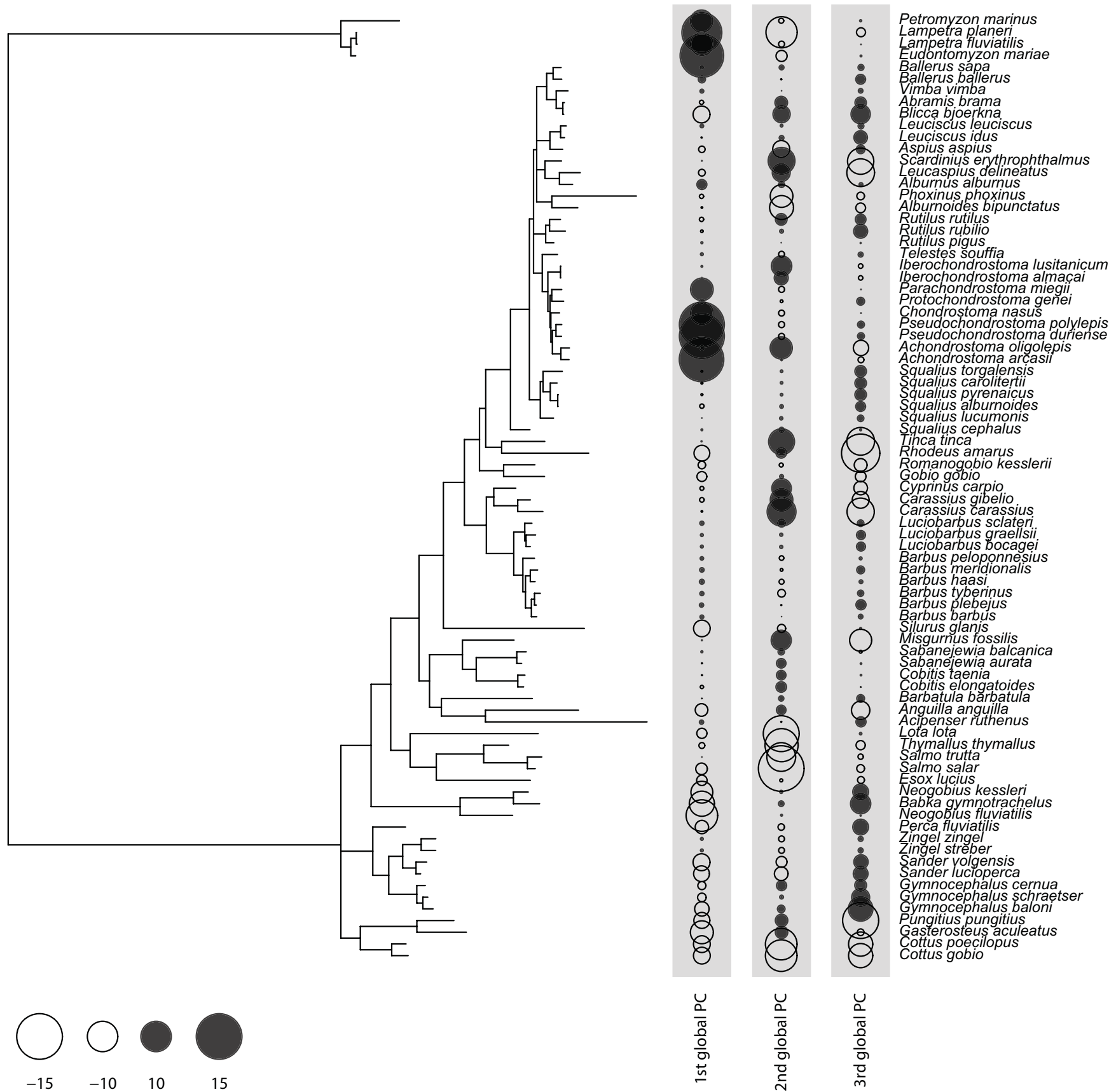

Fig. 2. The first three global components of the pPCA along the phylogenetic tree of European fish species. Negative and positive scores are indicated by white and black circles, respectively, and symbol sizes are proportional to their absolute values. 
The third global principal component contrasted bream, roach, Squalius species, barbels, gobiids and percids to carp, Scardinius erythrophthalmus, Leucaspius delineatus, tench, bitterling, gobiids, Misgurnus fossilis, eel, ninespine stickleback and cottids (Fig. 2). These species differed on the basis of their reproductive strategy (behaviour, spawning substrate and location), omnivorous feeding regime (OMNI), limnophilic habitat (LIMNO), tolerance of low oxygen concentrations (O2TOL) and stenothermia (STTHER) (Table 3).

Table 3: Trait state loadings and the first three axes of the pPCA.

\begin{tabular}{|c|c|c|c|c|}
\hline Trait & State & 1 st & 2 nd & $3 \mathrm{rd}$ \\
\hline \multirow{3}{*}{ Tolerance to oxygen } & O2IM & -0.0079 & -0.0417 & 0.0641 \\
\hline & O2INTOL & -0.0267 & 0.295 & -0.0797 \\
\hline & $\mathrm{O} 2 \mathrm{TOL}$ & 0.0586 & -0.2429 & -0.0998 \\
\hline \multirow{2}{*}{ Temperature tolerance } & EUTHER & 0.0134 & -0.0744 & 0.0396 \\
\hline & STTHER & -0.1068 & 0.5954 & -0.317 \\
\hline \multirow{3}{*}{ Tolerance to habitat degradation } & HIM & 0.0433 & -0.0485 & 0.1246 \\
\hline & HINTOL & 0.0736 & 0.1374 & -0.0918 \\
\hline & HTOL & -0.1487 & -0.1201 & -0.0319 \\
\hline \multirow{3}{*}{ Affinity to flow velocity } & EURY & -0.1406 & -0.0598 & 0.1167 \\
\hline & LIMNO & 0.0492 & -0.2314 & -0.3063 \\
\hline & RH & 0.0801 & 0.0928 & -0.0048 \\
\hline \multirow{2}{*}{ Feeding habitat } & B & 0.006 & -0.0441 & 0.0337 \\
\hline & WC & -0.0097 & 0.0711 & -0.0544 \\
\hline \multirow{5}{*}{ Trophic guild } & RARE & 0.3481 & 0.0678 & -0.1315 \\
\hline & DETR & 0.6671 & 0.0898 & -0.0422 \\
\hline & INSV & -0.1023 & 0.0232 & 0.0922 \\
\hline & OMNI & -0.0023 & -0.1945 & -0.1326 \\
\hline & PISC & -0.1727 & 0.3393 & 0.0566 \\
\hline \multirow{2}{*}{ Migration behaviour } & MIG & 0.098 & 0.1329 & 0.0871 \\
\hline & RESID & -0.064 & -0.0868 & -0.0569 \\
\hline \multirow{4}{*}{ Reproduction } & LITH & 0.085 & 0.0998 & 0.1118 \\
\hline & PHLI & -0.124 & -0.0848 & 0.2475 \\
\hline & PHYT & 0.0064 & -0.2006 & -0.3067 \\
\hline & RARE & -0.2429 & 0.051 & -0.3681 \\
\hline \multirow{3}{*}{ Spawning habitat } & EUPAR & -0.1509 & -0.0609 & 0.1828 \\
\hline & LIPAR & -0.1213 & -0.1661 & -0.4351 \\
\hline & RHPAR & 0.1188 & 0.0799 & 0.0148 \\
\hline \multirow{3}{*}{ Reproductive behaviour } & FR & -0.0222 & -0.197 & -0.2311 \\
\hline & PRO & -0.2953 & -0.0579 & 0.2545 \\
\hline & SIN & 0.0608 & 0.1123 & 0.0779 \\
\hline \multirow{2}{*}{ Parental care } & NOP & 0.0583 & -0.0409 & 0.0362 \\
\hline & PROT & -0.2789 & 0.1958 & -0.173 \\
\hline
\end{tabular}

\section{Fish assemblage functional structure}

The first factorial plane explained about two-thirds of the total inertia (F1: 48.1\%, F2: 15.3\%). The F1 axis displayed a strong association between traits reflecting tolerance, affinity to flow velocity and diet. The states STTHER, O2INTOL and HINTOL were highly correlated (Fig. 3) and associated with RH, RHPAR and INSV in the left part of the F1 axis. On the other hand, the states associated with tolerance, such as EUTHER, O2IM, HTOL, EURY, EUPAR and OMNI, 
were located in the right part of the F1 axis (Fig. 3).

The F2 axis distinguished between fish assemblages with regard to spawning habitat and migratory and reproductive behaviors. Fish assemblages characterized by potamodromous individuals (POTAD) spawning in running waters (RHPAR) only once a year (FR) were contrasted with fish assemblages with resident individuals (RESID) spawning repeatedly in a season (FR) but without spawning habitat preferences (EUPAR).

Some states seemed to be specific to particular assemblages. O2TOL, OMNI and PHLI occurred in less than $50 \%$ of the fish assemblages, whereas all other states were present in at least twothirds of the assemblages.

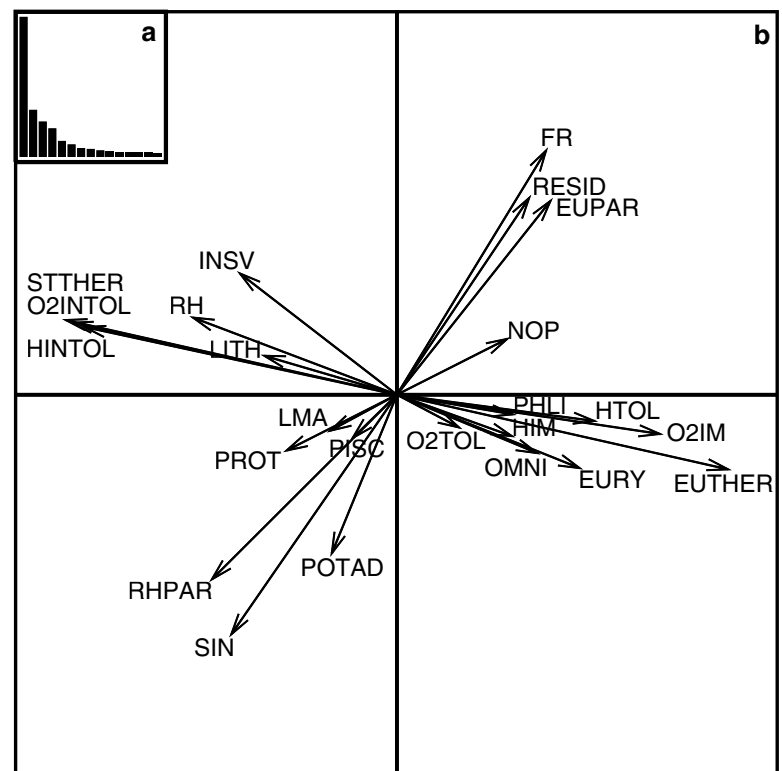

Fig. 3. First factorial plane of the PCA on the fish assemblage functional structure. Only the scores of the trait states with the highest contributions to the F1 and F2 axes are shown.

\section{Environmental influence}

The RDA significantly explained $30.5 \%$ of the inertia of the fish assemblage functional structure (permutations $F$-test, $p \leq 0.001$ ), suggesting a consistent influence of the environment on fish assemblage functional structure, even if a large portion of the inertia remains unexplained. The influence of the environment was reflected mostly by the first axis of the RDA $(83.2 \%$ of the explained inertia, permutations $F$-test, $p \leq 0.001$ ), thus by TJULY, SYNGEO1 and SLOP (Fig. $4 b)$. These variables were highly correlated with the F1 axis $(r=0.728,-0.645$ and -0.508 respectively, Fig. 4b), but TJULY was only slightly correlated with the other two variables $(r=0.127$ and 0.036$)$. All the environmental variables had a significant effect on fish assemblage functional structure, but TJULY had the greatest additional effect ( $F$-value $7-18$ times greater than the other two variables), followed by SYNGEO1 and TDIF (Table 4). The environmental 
variables considered seemed to have a slight influence on the reproductive and migration behavior gradients observed along the F2 axis of the PCA (Fig. 4b). These trait states were not distinguished clearly on the first factorial plane of the RDA compared to the first factorial plane of the PCA.

The fraction of fish assemblage functional structure variation explained only by TJULY and TDIF was greater than the fraction explained only by stream physical structure, $12.9 \%$ and $10.2 \%$, respectively, and their joint effect accounted for $6.8 \%$ of the variation in fish assemblage functional structure. Multicollinearity was a very limited phenomenon, as revealed by all GVIF values being lower than 2 .

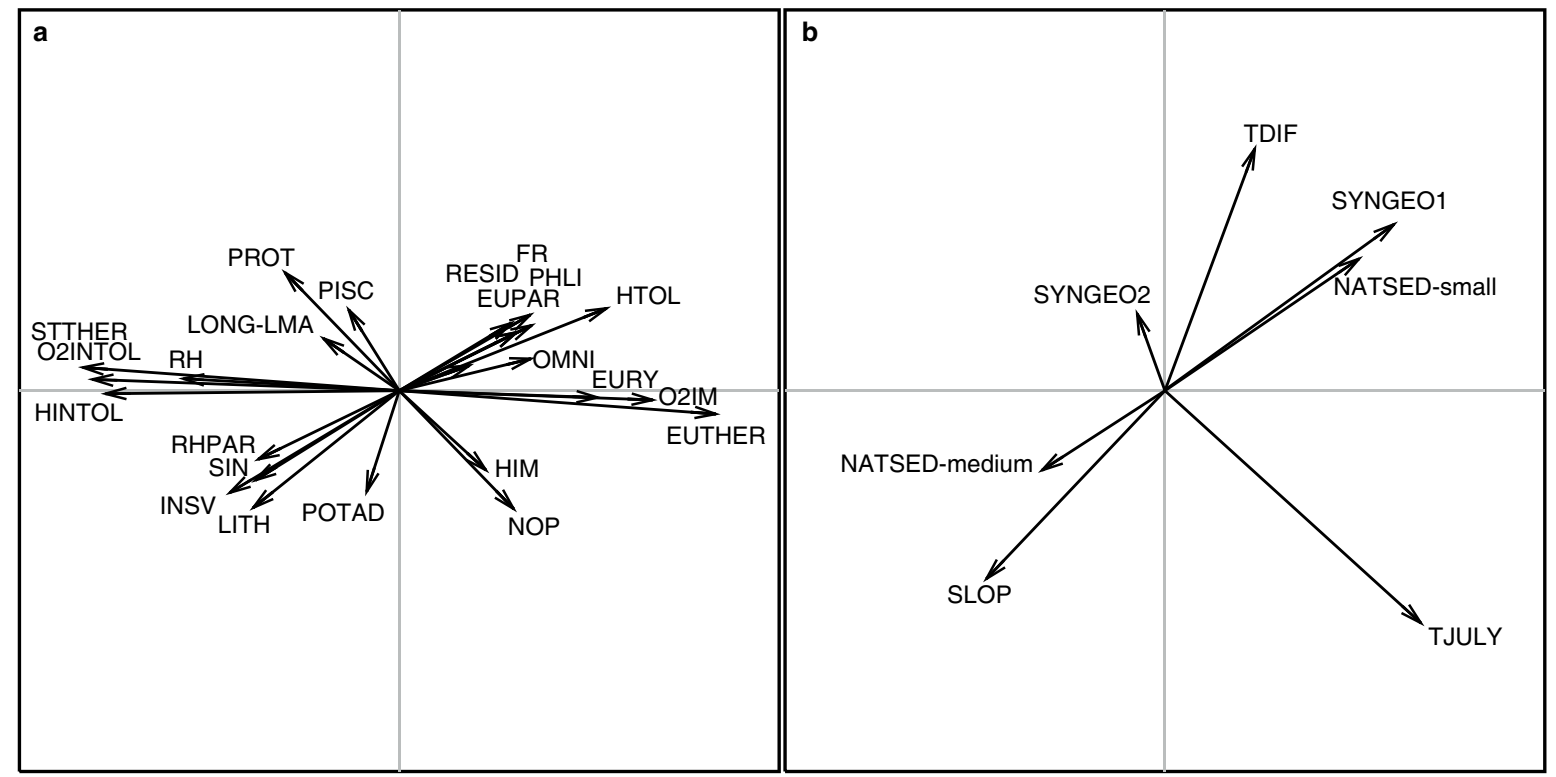

Fig. 4. a) Trait state scores predicted by the environment on the first factorial plane of the RDA (only the states with the highest contributions are represented). b) Correlations between the environmental variables and the fitted scores of sampling sites.

Table 4. Test of the marginal effect (once all other factors are controlled) of the environmental factors and the General Variance Inflation Factor (GVIF) of each variable

\begin{tabular}{llllll}
\hline Environmental factor & Df & F & N.Perm & $\operatorname{Pr}(>\mathrm{F})$ & GVIF \\
\hline TJULY & 1 & 136.7 & 999 & 0.001 & 1.13 \\
TDIF & 1 & 19.8 & 999 & 0.001 & 1.73 \\
SLOP & 1 & 11.1 & 999 & 0.001 & 1.62 \\
SYNGEO1 & 1 & 27.6 & 999 & 0.001 & 1.69 \\
SYNGEO2 & 1 & 7.6 & 999 & 0.001 & 1.49 \\
SED & 2 & 13.1 & 999 & 0.001 & 1.45 \\
\hline
\end{tabular}

\section{Biogeographic effect}

Biogegraphic regions explained $9.5 \%$ of the inertia of fish assemblage functional structure before taking the environment into account (999 permutations, F-test, $p \leq 0.001$ ), and only $2.2 \%$ 
afterwards (999 permutations, $F$-test, $p \leq 0.001$ ).

\section{Discussion}

The results highlight that European functional fish assemblages are structured following two main syndromes related to two main environmental gradients: river size and temperature. In addition, the results bring out the limitation of the influence of biogeographic regions on fish assemblage functional structure, once the effect of the environment is taken into account.

\section{Relations between ecological and biological characteristics}

The high percentage of inertia explained by the first factorial plane of the PCA $(66 \%)$ highlights strong associations between several species trait states among European fish assemblages. fish assemblage functional structure appears distributed along a gradient opposing two main syndromes (Poff et al. 2006, Frimpong and Angermeier 2010): (1) assemblages dominated by stenothermal individuals requiring a high concentration of dissolved oxygen and intolerant to habitat degradation and (2) assemblages dominated by eurytopic eurythermal individuals tolerant to habitat degradation and to low oxygen concentrations. To a lesser extent, the first axis also represents a trophic gradient, contrasting insectivorous and omnivorous species, and a gradient of affinity to flow velocity with rheophilic species contrasting with eurytopic species. Consequently, within European fish assemblages, several ecological traits appear to have co-evolved, resulting in only a few syndromes (Poff et al. 2006, Frimpong and Angermeier 2010). Even if the lifehistory strategies of European fish species have been studied previously (Vila-Gispert et al. 2002, Blanck and Lamouroux 2007, Blanck et al. 2007), this is the first time, to our knowledge, that such syndromes based on fish biological/ecological traits have been described at the European scale.

The second axis of the PCA reflects a reproductive gradient and distinguishes assemblages characterized by species displaying single reproduction in lotic areas from assemblages composed by species displaying fractional spawning in diverse spawning habitats. However, these results should be viewed with caution due to the lower inertia explained by the second axis, which could reflect noise in the data instead of relevant ecological patterns.

\section{Factors influencing ecological trait associations among European fish assemblages}

The environment explained a large proportion of the total variability in fish assemblage functional structure, in agreement with previous studies (Bremner et al. 2003, Pont et al. 2006, Hoeinghaus et al. 2007). Two major environmental gradients shape the functional structure of European fish assemblages: stream physical structure, varying along the longitudinal gradient (measured by stream size and slope), and the thermal gradient. Nevertheless, a substantial part of the fish assemblage functional structure variability still remains once the environmental effect has been controlled. This suggests that, in addition to the environmental variables considered, other 
factors not taken into account in this study, such as species interactions, might also influence functional assemblage structures (Cornwell and Ackerly 2009).

Nine sampled species were classified as intolerant to low oxygen concentrations, intolerant to habitat degradation and stenothermal, for example the brown trout (Salmo trutta), the bullhead (Cottus gobio) and the minnow (Phoxinus phoxinus). These species are typical of rithronic fish assemblages (Matthews 1998), preferring fast-flowing, cold and well-oxygenated waters (Elliott 1994, Crisp 2000, Blanck et al. 2007). The positive relationships of these states with slope and the first synthetic hydro-geomorphological variable and their negative relationships with mean July air temperature appear consistent with river functioning in temperate climates (Logez and Pont 2011). For instance, a high oxygen concentration in streams is associated with turbulent flow and low temperature, which is generally the case for small rivers in temperate countries.

The influence of slope on fish assemblages is well known (Huet 1954). As slope increases, the proportion of rheophilic individuals also increases (Oberdorff et al. 2002, Pont et al. 2007), while the proportion of eurytopic individuals decreases.

Numerous previous studies have also demonstrated the role played by temperature on the species composition of riverine assemblages (Rahel and Hubert 1991, Lyons 1996, Hawkins et al. 1997, Wehrly et al. 2003) and traits (Oberdorff et al. 2002, Pont et al. 2007, Friberg et al. 2009). Our results suggest that temperature is one of the main factors controlling fish assemblage functional structure at a continental scale.

At the European scale, temperature varies with latitude, altitude and continentality (Ward 1985, Koster 2005, Tockner et al. 2009). Therefore, since temperature varies at a larger scale than the longitudinal gradient of rivers, the influence of temperature on fish assemblage tends to overcome the influence of the longitudinal gradient.

The influence of environmental descriptors depends on the scale at which studies are conducted (Wiens 1989) and at which the variability of the descriptor is fully expressed (Angermeier and Winston 1999, Blackburn and Gaston 2002, Infante et al. 2009). If environmental descriptors such as 'hydraulic' (Poff and Allan 1995), varying over smaller spatial scales and acknowledged to be important drivers for fish assemblages, had been included here, the environment might have explained a greater portion of functional assemblage structure variability.

Moreover, the temporal variability of stream habitat might also influence fish assemblage functional structure since the variations in proportions of trait states observed along the environmental gradients follow the variation in habitat conditions (Goldstein and Meador 2004, Hoeinghaus et al. 2007, Friberg et al. 2009). Bêche et al. (2006) observed that in a fluctuating environment, the relative densities of species vary in accordance with habitat, and that the 
functional assemblage structure mirrors those fluctuations, even if species compositions are not modified. Assemblage structure seems to be more stable over years than taxonomic composition and species abundance (Bêche et al. 2006).

Along the longitudinal gradient, the proportion of insectivores decreased while the proportion of omnivores increased (with decreasing slope and increasing first synthetic hydrogeomorphological variable). This relative shift in trophic structure along the longitudinal gradient of streams has been observed on different continents (Ibañez et al. 2009): in Europe (Oberdorff et al. 2002, Pont et al. 2007), North America (McGarvey and Hughes 2008) and Africa (Ibañez et al. 2007).

Phylogenetic relatedness between species appears to influence the co-occurrence of species traits among species (Vitt and Pianka 2005) and, consequently, functional assemblage structure. Functional structure convergences are likely to arise between assemblages composed of phylogenetically close species pools (Bellwood et al. 2002), whereas Smith and Ganzhorn (1996) observed divergent functional structure between mammal assemblages that were composed of species from different families. Nevertheless, even for traits which seem to be constrained, phylogenetically distant species might present the same syndromes, suggesting that environmental selection might lead to convergence between traits (Poff et al. 2006, Pavoine et al. 2011), and that environment probably has a greater effect on fish assemblage structure than phylogeny. This hypothesis is still untested and, even if some statistical analyses are available (Desdevises et al. 2003, Pavoine et al. 2011), additional work and further methodological development are needed to be able to quantify the relative influence of these two factors on assemblage structure.

\section{Regional factors}

The relative stability of fish assemblage functional structure between biogeographic regions, after removing environment, suggest that the selective forces driven by the environment are consistent among these regions, whatever the differences between the species pools (Bremner et al. 2003, Hewitt et al. 2008, Horrigan and Baird 2008), leading to a convergent assemblage structure (Bellwood and Hughes 2001). This relative stability also suggests that species living in different areas but in similar environmental conditions may play the same ecological role or function (Angermeier and Winston 1999, Bremner et al. 2006).

Previous studies have demonstrated that local environmental conditions might explain and predict individual trait states (Bellwood and Hughes 2001, Lamouroux et al. 2002, Oberdorff et al. 2002, Lamouroux et al. 2004, Pont et al. 2006, Ibañez et al. 2007, Pont et al. 2007). Our study supports the hypothesis that a low number of multiple combinations of functional traits might have simultaneously co-evolved in response to environmental gradients (Hoeinghaus et al. 2007). 
Consequently, the adaptive value of a given trait makes sense only with regard to other trait values (Townsend et al. 1997, Poff et al. 2006, Verberk et al. 2008). Nevertheless, determining how many traits might enable the presence of a species in a given environment remains difficult, because a single trait or a combination of traits might be necessary, depending on species and environmental conditions (Townsend and Hildrew 1994).

\section{Acknowledgements}

Work on this manuscript was funded by the European Commission under the Sixth Framework Programme (EFI+ project, contract number 044096). We are grateful to all members who took part in this project. This paper is also a result of the project WISER (Water bodies in Europe: Integrative Systems to assess Ecological status and Recovery) funded by the European Union under the 7th Framework Programme, Theme 6 (Environment including Climate Change) (contract No. 226273), http:// www.wiser.eu. We thank Thierry Oberdorff and three anonymous referees for comments that have greatly improved this manuscript. We are also grateful to $\mathrm{T}$. Jombart and S. Pavoine for their valuable advice and their material support with the phylogenetic analyses.

\section{References}

Allan, J. D. and Castillo, M. M. 2007. Stream ecology: structure and function of running waters. - Kluwer Acad. Publ.

Angermeier, P. L. and Winston, M. R. 1999. Characterizing fish community diversity across Virginia landscapes: prerequisite for conservation. - Ecol. Appl. 9: 335-349.

Banarescu, P. 1989. Zoogeography and history of the freshwater fish fauna of Europe. - In: Holcik, J. (ed), The freshwater fishes of Europe. Aula-Verlag, pp. 88-107.

Barnett, A. J. et al. 2007. Functional diversity of crustacean zooplankton communities: towards a trait-based classification. - Freshw. Biol. 52: 796-813.

Bêche, L. A. et al. 2006. Long-term seasonal variation in the biological traits of benthicmacroinvertebrates in two Mediterranean-climate streams in California, USA. - Freshw. Biol. 51: 56-75.

Bellwood, D. R. and Hughes, T. P. 2001. Regional-scale assembly rules and biodiversity of coral reefs. - Science 292: 1532-1534.

Bellwood, D. R et al. 2002. Assembly rules and functional groups at global biogeographical scales. - Funct. Ecol. 16: 557-562.

Blackburn, T. M. and Gaston, K. J. 2002. Scale in macroecology. - Glob. Ecol. Biogeogr. 11: 185-189.

Blanck, A. and Lamouroux, N. 2007. Large-scale intraspecific variation in life-history traits of European freshwater fish. - J. Biogeogr. 34: 862-875.

Blanck, A. et al. 2007. Relationships between life-history strategies of European freshwater fish species and their habitat preferences. - Freshw. Biol. 52: 843-859.

Bremner, J. et al. 2003. Assessing functional diversity in marine benthic ecosystems: a comparison of approaches. - Mar. Ecol. Prog. Ser. 254: 11-25. 
Bremner, J. et al. 2006. Matching biological traits to environmental conditions in marine benthic ecosystems. - J. Mar. Syst. 60: 302-316.

Chessel, D. et al. 2004. The ade4 package -I- one-table methods. - R News. 4: 5-10.

Cornwell, W. K. and Ackerly, D. D. 2009. Community assembly and shifts in plant trait distributions across an environmental gradient in coastal California. - Ecol. Monogr. 79: 109-126.

Cornwell, W. K. et al. 2006. A trait-based test for habitat filtering: convex hull volume. Ecology 87: 1465-1471.

Crisp, D. T. 2000. Trout and salmon: ecology, conservation and rehabilitation. — Fishing News Books.

Desdevises, Y. et al. 2003. Quantifying phylogenetically-structured environmental variation. Evolution 57: 2647-2652.

Diaz, S. et al. 1998. Plant functional traits and environmental filters at a regional scale. - J. Veg. Sci. 9: 113-122.

Dray, S. et al. 2008. Spatial ordination of vegetation data using a generalization of Wartenberg's multivariate spatial correlation. - J. Veg. Sci. 19: 45-56.

Elliott, J. M. 1994. Quantitative ecology and the brown trout. - Oxford Univ. Press.

European Union (EC) 2000. Directive 2000/60/EC of the European Parliament and of the council establishing a framework for the community action in the field of water policy. - Off. J. Eur. Commun. L327: 1-72.

Fox, J. 2002. An R and S Plus companion to applied regression. - Sage.

Friberg, N. et al. 2009. Relationships between structure and function in streams contrasting in temperature. - Freshw. Biol. 54: 2051-2068.

Frimpong, E. A. and Angermeier, P. L. 2010. Trait-based approaches in the analysis of stream fish communities. - Am. Fish. Soc. Symp. 73: 109-136.

Goldstein, R. M. and Meador, M. R. 2004. Comparisons of fish species traits from small streams to large rivers. - Trans. Am. Fish. Soc. 133: 971-983.

Hawkins, C. P. et al. 1997. Channel morphology, water temperature, and assemblage structure of stream insects. - J. N. Am. Benthol. Soc 16: 728-749.

Hewitt, J. E. et al. 2008. Habitat variation, species diversity and ecological functioning in a marine system. - J. Exp. Mar. Biol. Ecol. 366: 116-122.

Hijmans, R. J. et al. 2005. Very high resolution interpolated climate surfaces for global land areas. - Int. J. Climatol. 25: 1965-1978.

Hill, M. O. and Smith, A. J. E. 1976. Principal component analysis of taxonomic data with multistate discrete characters. - Taxon 25: 249-255.

Hoeinghaus, D. J. et al. 2007. Local and regional determinants of stream fish assemblage structure: inferences based on taxonomic vs. functional groups. - J. Biogeogr. 34: 324338.

Horrigan, N. and Baird, D. J. 2008. Trait patterns of aquatic insects across gradients of flowrelated factors: a multivariate analysis of Canadian national data. - Can. J. Fish. Aquat. Sci. 65: 670-680.

Huet, M. 1954. Biologie, profils en long et en travers des eaux courantes. - Bull. Fr. Piscic. 175: 


\section{1-53.}

Ibañez, C. et al. 2007. Fish assemblages structure and function along environmental gradients in rivers of Gabon (Africa). — Ecol. Freshw. Fish. 16: 315-334.

Ibañez, C. et al. 2009. Convergence of temperate and tropical stream fish assemblages. Ecography 32: 658-670.

Infante, D. et al. 2009. Relationship of fish and macroinvertebrate assemblages to environmental factors: implications for community concordance. - Hydrobiologia 623: 87-103.

Irz, P. et al. 2007. Fish community comparisons along environmental gradients in lakes of France and north-east USA. - Glob. Ecol. Biogeogr. 16: 350-366.

Jombart, T. et al. 2010a. adephylo: new tools for investigating the phylogenetic signal in biological traits. - Bioinformatics 26: 1907-1909.

Jombart, T. et al. 2010b. Putting phylogeny into the analysis of biological traits: a methodological approach. - J. Theor. Biol. 264: 693-701.

Junk, W. J. et al. 1989. The flood pulse concept in river-floodplain systems. — In: Dodge, D. P. (ed), Proceedings of the international large river symposium (LARS). Canadian Journal of Fisheries and Aquatic Sciences Special Publication, pp. 110-127.

Keddy, P. A. 1992. Assembly and response rules: two goals for predictive community ecology. - J. Veg. Sci. 3: 157-164.

Kelt, D. A. et al. 1996. Community structure of desert small mammals: comparisons across four continents. - Ecology 77: 746-761.

Koster, E. A. 2005. The physical geography of Western Europe. - Oxford Univ. Press.

Lamouroux, N. et al. 2002. Intercontinental convergence of stream fish community traits along geomorphic and hydraulic gradients. - Ecology 83: 1792-1807.

Lamouroux, N. et al. 2004. Biological traits of stream macroinvertebrate communities: effects of microhabitat, reach, and basin filters. - J. N. Am. Benthol. Soc 23: 449-466.

Larkin, M. A. et al. 2007. Clustal W and Clustal X version 2.0. - Bioinformatics 23: 2947-2948.

Lavorel, S. and Garnier, E. 2002. Predicting changes in community composition and ecosystem functioning from plant traits: revisiting the holy grail. - Funct. Ecol. 16: 545-556.

Lebreton, J. D. et al. 1991. Principal component and correspondence analyses with respect to instrumental variables: an overview of their role in studies of structure-activity and speciesenvironment relationships. - In: Devillers, J. and Karcher, W. (eds), Applied multivariate analysis in SAR and environmental studies. Kluwer Academic Publishers, pp. 85-114.

Legendre, L. and Legendre, P. 1998. Numerical ecology. — Elsevier Science B.V.

Legendre, P. et al. 2011. Testing the significance of canonical axes in redundancy analysis. Method. Ecol. Evol. 2: 269-277.

Logez, M. and Pont, D. 2011. Development of metrics based on fish body size and species traits to assess European coldwater streams. - Ecol. Indic. 11: 1204-1215.

Logez, M. et al. 2010. Do Iberian and European fish faunas exhibit convergent functional structure along environmental gradients? - J. N. Am. Benthol. Soc. 29: 1310-1323.

Lyons, J. 1996. Patterns in the species composition of fish assemblages among Wisconsin streams. - Environ. Biol. Fishes 45: 329-341.

MacArthur, R. and Levins, R. 1967. The limiting similarity, convergence, and divergence of 
coexisting species. - Am. Nat. 101: 377-385.

Mason, N. W. H. et al. 2007. Functional characters combined with null models reveal inconsistency in mechanisms of species turnover in lacustrine fish communities. Oecologia 153: 441-452.

Matthews, W. J. 1998. Patterns in freshwater fish ecology. — Chapman \& Hall.

McGarvey, D. J. and Hughes, R. M. 2008. Longitudinal zonation of Pacific Northwest (U.S.A.) fish assemblages and the species-discharge relationship. - Copeia 2008: 311-321.

Melcher, A. et al. 2007. Spatially based methods to assess the ecological status of European fish assemblage types. - Fish. Manag. Ecol. 14: 453-463.

Melville, J. et al. 2006. Intercontinental community convergence of ecology and morphology in desert lizards. - Proc. R. Soc. Biol. Sci. Ser. B 273: 557-563.

Mims, M. C. et al. 2010. Life history trait diversity of native freshwater fishes in north America. - Ecol. Freshw. Fish. 19: 390-400.

Noble, R. A. A. et al. 2007. Assessing the health of European rivers using functional ecological guilds of fish communities: standardising species classification and approaches to metric selection. - Fish. Manag. Ecol. 14: 381-392.

Oberdorff, T. et al. 2002. Development and validation of a fish-based index for the assessment of 'river health' in France. - Freshw. Biol. 47: 1720-1734.

Oksanen, J. et al. 2011. Vegan: community ecology package.

Olden, J. D. and Kennard, M. J. 2010. Intercontinental comparison of fish life history strategies along a gradient of hydrologic variability. - Am. Fish. Soc. Symp. 73: 83-107.

Orians, G. H. and Paine, R. T. 1983. Convergent evolution at the community level. - In: Futuyma, D. J. and Slatkin, M. (eds), Coevolution. Sinauer, pp. 431-458.

Pavoine, S. et al. 2009. On the challenge of treating various types of variables: application for improving the measurement of functional diversity. - Oikos 118: 391-402.

Pavoine, S. et al. 2010. Decomposition of trait diversity among the nodes of a phylogenetic tree. — Ecol. Monogr. 80: 485-507.

Pavoine, S. et al. 2011. Linking patterns in phylogeny, traits, abiotic variables and space: a novel approach to linking environmental filtering and plant community assembly. - J. Ecol. 99: $165-175$.

Peres-Neto, P. R. et al. 2006. Variation partitioning of species data matrices: estimation and comparison of fractions. - Ecology 87: 2614-2625.

Petts, G. E. and Amoros, C. 1996. Fluvial hydrosystems. — Chapman \& Hall.

Poff, N. L. 1997. Landscape filters and species traits: towards mechanistic understanding and prediction in stream ecology. - J. N. Am. Benthol. Soc. 16: 391-409.

Poff, N. L. and Allan, J. D. 1995. Functional organization of stream fish assemblages in relation to hydrological variability. - Ecology 76: 606-627.

Poff, N. L. et al. 2006. Functional trait niches of North American lotic insects: traits-based ecological applications in light of phylogenetic relationships. - J. N. Am. Benthol. Soc. 25: 730-755.

Pont, D. et al. 2005. Modelling habitat requirement of European fishes: do species have similar responses to local and regional environmental constraints? - Can. J. Fish. Aquat. Sci. 62: 
163-173.

Pont, D. et al. 2006. Assessing river biotic condition at a continental scale: a European approach using functional metrics and fish assemblages. - J. Appl. Ecol. 43: 70-80.

Pont, D. et al. 2007. Development of a fish-based index for the assessment of river health in Europe: the European fish index. — Fish. Manag. Ecol. 14: 427-439.

R Development Core Team 2011. R: a language and environment for statistical computing. - R Foundation for Statistical Computing.

Rahel, F. J. and Hubert, W. A. 1991. Fish assemblages and habitat gradients in a RockyMountain Great-Plains stream: biotic zonation and additive patterns of community change. — Trans. Am. Fish. Soc. 120: 319-332.

Rao, C. R. 1964. The use and interpretation of principal component analysis in applied research. - Sankhya Ser. A. 26: 329-358.

Reyjol, Y. et al. 2007. Patterns in species richness and endemism of European freshwater fish. Glob. Ecol. Biogeogr. 16: 65-75.

Ronquist, F. and Huelsenbeck, J. P. 2003. Mrbayes 3: bayesian phylogenetic inference under mixed models. - Bioinformatics 19: 1572-1574.

Schleuter, D et al. 2012. Geographic isolation and climate govern the functional diversity of native fish communities in European drainage basins. - Glob. Ecol. Biogeogr.

Smith, A. P. and Ganzhorn, J. U. 1996. Convergence in community structure and dietary adaptation in Australian possums and gliders and Malagasy lemurs. - Aust. J. Ecol. 21: 3146.

Southwood, T. R. E. 1977. Habitat, the templet for ecological strategies? - J. Anim. Ecol. 46: 337-365.

Southwood, T. R. E. 1988. Tactics, strategies and templets. - Oikos 52: 3-18.

Statzner, B. et al. 2004. Biological trait composition of European stream invertebrate communities: assessing the effects of various trait filter types. - Ecography 27: 470-488.

Stearns, S. 1992. The evolution of life histories. - Oxford Univ. Press.

Tavaré, S. 1986. Some probabilistic and statistical problems in the analysis of DNA sequences. — Lectures Math. Life Sci. 17: 57-86.

Tedesco, P. A. et al. 2008. River hydrological seasonality influences life history strategies of tropical riverine fishes. - Oecologia 156: 691-702.

Tockner, K. et al. 2009. Rivers of Europe. - Acad. Press.

Tonn, W. M. et al. 1990. Intercontinental comparison of small-lake fish assemblages: the balance between local and regional processes. - Am. Nat. 136: 345-375.

Townsend, C. R. and Hildrew, A. G. 1994. Species traits in relation to a habitat templet for river systems. - Freshw. Biol. 31: 265-275.

Townsend, C. R. et al. 1997. Species traits in relation to temporal and spatial heterogeneity in streams: a test of habitat templet theory. - Freshw. Biol. 37: 367-387.

Usseglio-Polatera, P. et al. 2000. Biological and ecological traits of benthic freshwater macroinvertebrates: relationships and definition of groups with similar traits. - Freshw. Biol. 43: 175-205.

Verberk, W. C. E. P. et al. 2008. Life-history strategies in freshwater macroinvertebrates. - 
Freshw. Biol. 53: 1722-1738.

Vila-Gispert, A. et al. 2002. Gradients of life-history variation: an intercontinental comparison of fishes. - Rev. Fish Biol. Fish. 12: 417-427.

Vitt, L. J. and Pianka, E. R. 2005. Deep history impacts present-day ecology and biodiversity. Proc. Natl. Acad. Sci. U. S. A. 102: 7877-7881.

Ward, J. V. 1985. Thermal-characteristics of running waters. - Hydrobiologia 125: 31-46.

Webb, C. O., Ackerly, D. D., McPeek, M. A. and Donoghue, M. J. 2002. Phylogenies and community ecology. - Annu. Rev. Ecol. Syst. 33: 475-505.

Wehrly, K. E. et al. 2003. Classifying regional variation in thermal regime based on stream fish community patterns. - Trans. Am. Fish. Soc. 132: 18-38.

Weiher, E. and Keddy, P. A. 1995. Assembly rules, null models, and trait dispersion: new questions front old patterns. - Oikos 74: 159-164.

Weiher, E. and Keddy, P. 1999. Ecological assembly rules: perspectives, advances, retreats. Cambridge Univ. Press.

Wiens, J. A. 1989. Spatial scaling in ecology. — Funct. Ecol. 3: 385-397.

Wiens, J. A. 1991. Ecological similarity of shrub-desert avifaunas of Australia and North America. - Ecology 72: 479-495.

Willby, N. J. et al. 2000. Attribute-based classification of European hydrophytes and its relationship to habitat utilization. - Freshw. Biol. 43: 43-74.

Winemiller, K. O. 2005. Life history strategies, population regulation, and implications for fisheries management. - Can. J. Fish. Aquat. Sci. 62: 872-885.

Winemiller, K. O. and Rose, K. A. 1992. Patterns of life-history diversification in NorthAmerican fishes: implications for population regulation. - Can. J. Fish. Aquat. Sci. 49: 2196-2218. 